\title{
Analisis dan Perancangan Software Pemetaan Struktur Organisasi dengan Model Proses Bisnis Menggunakan Kemiripan Makna Kata
}

\author{
Nurul Hidayah ${ }^{1, *}$, Febrina Dwitasari ${ }^{2}$, Laila Zahrona ${ }^{3}$, Muhammad Ainul Yaqin $^{4}$ \\ Jurusan Teknik Informatika, Universitas Islam Negeri Maulana Malik Ibrahim, Indonesia \\ ${ }^{1}$ nhurulhidayahlubis@gmail.com; ${ }^{2}$ febrinadwitasari01@gmail.com; ${ }^{3}$ ilalaila909@gmail.com; ${ }^{4}$ yaqinov@ $@$ ti.uin- \\ malang.ac.id \\ *corresponding author
}

INFO ARTIKEL

Sejarah Artikel

Diterima: 15 Desember 2019

Direvisi: 5 Mei 2020

Diterbitkan: 30 Agustus 2020

Kata Kunci

Struktur Organisasi

Model Proses Bisnis

Kemiripan Makna Kata

\section{ABSTRAK}

Struktur organisasi menetapkan bagaimana tugas pekerjaan dibagi, dikelompokkan, dan dikoordinasikan secara formal. Model proses bisnis merupakan representasi dari fungsi-fungsi yang berkaitan dengan kegiatan bisnis seperti input, control, output dan source. Pada hakikatnya sebuah organisasi dan model proses bisnis yang ada memiliki keterkaitan didalamnya, salah satunya dengan memetakan kemiripan makna katanya. Untuk mendapatkan kemiripan makna kata penelitian disini menggunakan podok pesantren sebagai studi kasus untuk mendapatkan kemiripan makna kata yang diharapkan, kemudian menghitung persamaan makna kata melalui job description pondok pesantren tersebut menggunakan perhitungan sentence similarity. Perhitungan sentence similarity bertujuan untuk menghitung nilai kemiripan secara keseluruhan dalam bentuk kalimat menjadi suatu kemiripan secara utuh. Perhitungan word similarity dihitung menggunakan Word Similarity for Java (WS4J) dengan pendekatan PATH dan TF-IDF. Dalam Penelitian ini, Pengaruh sentence similarity dalam job description kegiatan pendaftaran mahasantri yang dibandingkan hampir mirip, meskipun pada beberapa job description masih mempunyai nilai yang beda jauh untuk kemiripannya. Sehingga dihasilkannya kemiripan makna kata yang benar dari struktur organisasi berupa tupoksi yang ada dengan model proses bisnis yg dijalankan didalamnya.

\section{PENDAHULUAN}

Pada dasarnya organisasi adalah sebuah wadah di dalamnya terdapat banyak orang berkumpul, bekerja sama secara rasional dan sistematis, terencana, terpimpin dan terkendali, dalam memanfaatkan sumber daya (uang, material, mesin, metode, lingkungan) saranaparasarana, data, dan lain sebagainya yang digunakan secara efisien dan efektif untuk mencapai tujuan organisasi. Sedangkan Grenberg dan Baron berpendapat bahwa organisasi adalah sistem sosial yang terstruktur terdiri dari kelompok dan individu bekerja sama untuk mencapai beberapa sasaran yang disepakati [1]. Organisasi merupakan usaha yang dilakukan dengan mengkoordinir kegiatan dalam pembagian tugas, tugas tersebut mempunyai tujuan bersama dan dapat dipertanggungjawabkan. Pemahaman organisasi mendekati pendapat Schein. Organisasi dapat terbentuk apabila suatu usaha memerlukan dari satu orang dalam menyelesaikan suatu kegiatan [2].

Sebuah organisasi dapat terbentuk karena dipengaruhi oleh beberapa aspek seperti penyatuan visi dan misi serta tujuan yang sama dengan perwujudan eksistensi sekelompok orang tersebut terhadap masyarakat. Kinerja suatu organisasi tergantung pada kerja pegawainya. Namun, atasan dapat berperan dalam merencanakan, melaksanakan, dan 
mengendalikan suatu organisasi. Dalam hal ini, atasan harus mempunyai peran yang penting dalam usahanya untuk memotivasi dan mengelola pegawainya. Organisasi perlu memberikan perhatian khusus terhadap prestasi yang diperoleh oleh pegawai dengan cara pemberian reward (hadiah, imbalan, dan penghargaan) dan motivasi untuk bekerja penuh semangat, memiliki tanggung jawab yang tinggi terhadap tugasnya, sehingga suatu organisasi akan mudah dalam memenuhi tujuan yang direncanakan [3]. Orang-orang yang ada di dalam suatu organisasi mempunyai suatu keterkaitan yang terus menerus, kita menyebutnya dengan struktur organisasi. Menurut Robbins, suatu struktur organisasi menetapkan bagaimana tugas pekerjaan dibagi, dikelompokkan, dan dikoordinasikan secara formal [3]. Pembentukan struktur, walaupun hanya menyajikan kerangka bangunan organisasi merupakan suatu sub-sistem penting dari organisasi. Dengan adanya struktur organiasi semua kegiatan dapat terstruktur salah satunya dengan model proses bisnis. Model proses bisnis adalah representasi dari fungsi-fungsi yang berkaitan dengan kegiatan bisnis seperti input, control, output, resource. Model proses bisnis dimanfaatkan untuk mengidentifikasi bagian-bagian mana saja yang masih perlu diperbaiki dari proses bisnis tersebut. Proses bisnis dapat dipahami sebagai kumpulan aktivitas yang dapat mendefinisikan business event dan pekerjaan yang dilakukan oleh sebuah sistem untuk merubah input menjadi output yang bernilai tambah bagi pengguna. Model proses bisnis bisa digunakan sebagai dasar dalam mengidentifikasi kebutuhan pengguna yang merupakan bagian utama dalam pengembangan sistem informasi enterprise. Model proses bisnis bisa, dikelompokkan atas 9 (sembilan) tahapan Gambar 1, yang menggambarkan siklus dari model proses yang akan dilakukan dalam menghasilkan sistem informasi enterprise.[4] Jadi model proses bisnis merupakan serangkaian aktivitas bisnis yang disusun secara spesifik, bergantung pada aturan bisnis yang diterapkan oleh setiap perusahaan. Proses bisnis sangat berguna untuk menganalisis suatu organisasi, dalam hal ini mengatur setiap departemen dan aktivitas operasional dengan pendekatan sistematik yang bertujuan untuk mencapai peningkatan kualitas yang diinginkan [5].

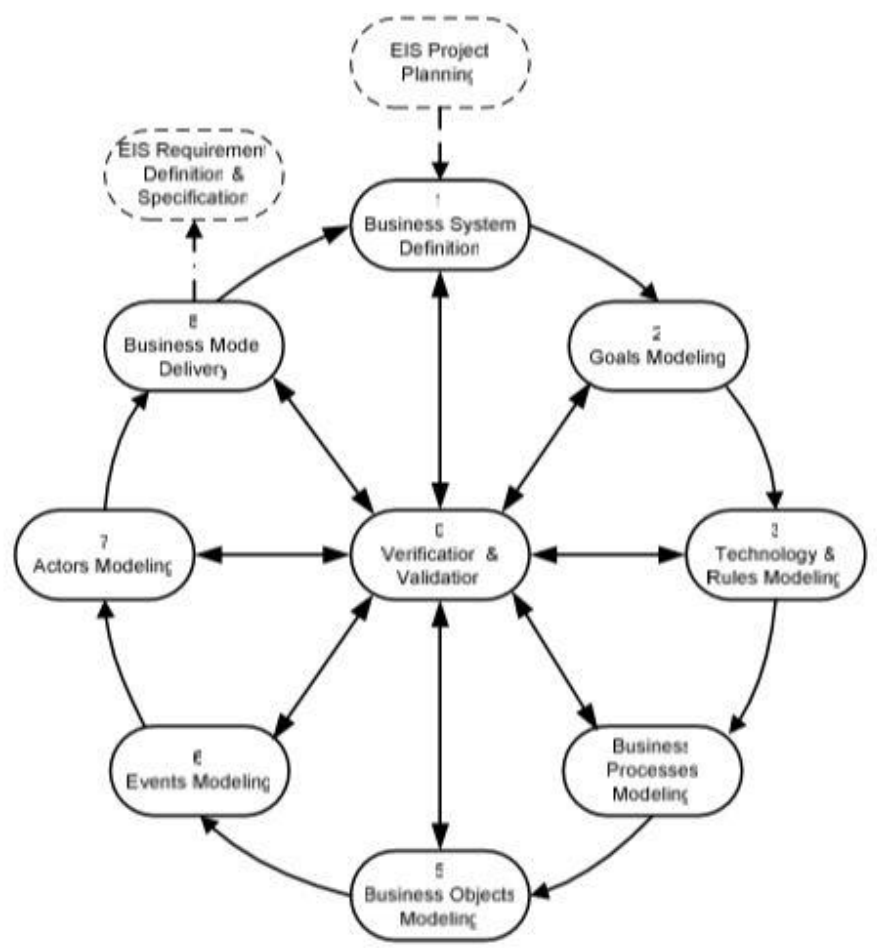

Gambar 1. Business Process Model 
Didalam struktur oraganisasi terdapat banyak kata yang di dalamnya ada berbagai kata yang memiliki kemiripan makna atau sering disebut kesamaan simentik. Semantik adalah cabang dari linguistik (ilmu bahasa) yang mempelajari arti atau makna yang terkandung pada suatu bahasa, kode, atau jenis representasi lain, atau yang lebih dikenal dengan pembelajaran tentang makna. Kata semantik itu sendiri menunjukkan berbagai ide dari populer yang sangat teknis. Hal ini sering digunakan dalam Bahasa [6]. Kesamaan semantik atau semantic similarity digunakan untuk mengidentifikasi konsep-konsep yang memiliki kesamaan "karakteristik". Meskipun manusia tidak tahu definisi formal keterkaitan antara konsep, kesamaan semantik bisa menilai keterkaitan antara mereka [6]. Kesamaan semantik adalah metrik yang didefinisikan di atas seperangkat dokumen atau kata, dimana gagasan jarak antara keduanya didasarkan pada kemiripan makna atau konten semantiknya dibandingkan dengan kesamaan yang dapat diperkirakan mengenai representasi sintaksis mereka. Kesamaan semantik juga merupakan alat matematika yang digunakan untuk memperkirakan kekuatan hubungan semantik antara unit bahasa, konsep atau contoh, melalui deskripsi numeric yang diperoleh sesuai dengan perbandingan informasi yang mendukung maknanya atau menggambarkan sifatnya [7].

Dalam membandingkan kemiripan antar kata yang satu dengan yang lain disesuaikan dengan masing-masing jenis kelas katanya. Perbandingan antar kata hanya dapat dilakukan dengan kata yang memiliki jenis kelas kata yang sama. Sedangkan kemiripan makna kalimat yaitu gabungan dari kemiripan antar kata. Untuk mengetahui kedekatan makna antar kalimat maka dapat dilakukan dengan cara menghitung nilai kemiripan makna antar kalimat tersebut. Dalam pemetaan struktur organisasi dengan model proses bisnis menggunakan kata, melalu tahapan pengumpulan data, pre-process, menghitung persamaan kata. Berdasarkan uraian singkat diatas, penulis memahami dalam struktur organisasi kita bisa melihat salah satu dari sistem pendidikan atau lebih spesifiknya penulis mengambil studi kasus struktur organisasi pada suatu pondok pesantren yang telah ditetapkan dan dapat kita ukur kemiripan makna katanya dengan model proses bisnis menggunakan kemiripan makna kata. Setelah melakukan model proses bisnis kemudian kemiripan makna kata akan dibandingkan menggunakan metode $P A T H$. Sehingga dihasilkannya kemiripan makna kata yang benar dari struktur organisasi berupa tupoksi yang ada dengan model proses bisnis yg dijalankan didalamnya.

\section{METODE}

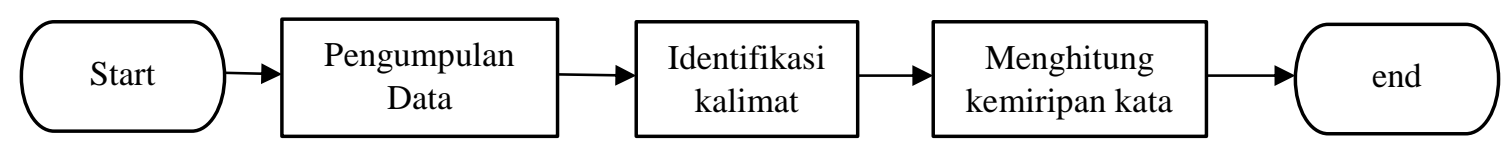

Gambar 2. Prosedur Penelitian

Gambar 2 merupakan alur proses penelitian mulai dari pengumpulan data hingga menghitung nilai kemiripan kata.

\section{Pengumpulan Data}

Pengumpulan data pada penelitian ini adalah dari data sekunder. Data sekunder merupakan data yang telah dikumpulkan untuk maksud selain menyelesaikan masalah yang dihadapi. Data ini dapat ditemui dengan cepat. Dalam penelitian ini yang menjadi sumber data sekunder adalah literatur, artikel, jurnal serta situs di internet yang berkenaan dengan penelitian yang dilakukan. 
Dalam sumber lain disebutkan bahwa sumber data sekunder merupakan sumber yang tidak langsung memberikan data kepada pengumpul data. Adapun data sekunder dari penelitian bersumber dari dokumen-dokumen berupaka catatan, rekaman gambar atau foto-foto dan hasil obeservasi yang berhubungan dengan fokus penelitian ini. Data yang digunakan pada penelitian ini adalah job description dari struktur organisasi pondok pesantren yaitu Job description dari bidang kesantrian. Pada tabel 1 merupakan job description dari bidang tersebut :

Tabel 1. Data Tupoksi dan Model proses bisnis

\begin{tabular}{|l|l|l|}
\hline No. & Data & \multicolumn{2}{|c|}{ Dokumen } \\
\hline 1. & $\begin{array}{l}\text { Tugas } \\
\text { pokok } \\
\text { dan } \\
\text { funsgi }\end{array}$ & $\begin{array}{l}\text { Mengelola buku induk dan kartu santri, Mengelola surat masuk dan surat keluar, } \\
\text { Menyusun kearsipan pondok, Merealisasikan Bantuan Operasional Pondok (BOP) } \\
\text { dan Dana Hibah, Menerima dan melayani pendaftaran santri baru, } \\
\text { Mendokumentasikan kegiatan pondok, Mendata barang Inventaris, } \\
\text { mensosialisasikan peraturan dan kegiatan pondok kepada wali santri. }\end{array}$ \\
\hline 2. & $\begin{array}{l}\text { Model } \\
\text { Proses } \\
\text { Bisnis }\end{array}$ & $\begin{array}{l}\text { Membuat pengumuman pendaftaran, menerima berkas pendaftaran, } \\
\text { mengumumkan jadwal tes, melakukan koreksi, mengumumkan hasil tes. }\end{array}$ \\
\hline
\end{tabular}

\section{Identifikasi Kalimat}

Identifikasi kalimat merupakan tahap setelah pengumpulan data, pada tahap ini dilakukukan dengan cara memilah kalimat dari data organisasi dengan model proses bisnis. Proses yang dilakukan untuk menentukan jenis kata pada kalimat yaitu menggunakan text mining. Berikut tahapan-tahapan dari text minning :

\section{Case Folding}

Case folding merupakan proses untuk mengubah semua teks dokumen menjadi huruf kecil [8]. Ini dilakukan untuk mempermudah pencarian. Tidak semua dokumen teks konsisten dalam penggunaan huruf kapital. Oleh kerena itu peran case folding dibutuhkan dalam mengkonversi keseluruhan teks dalam dokumen menjadi suatu bentuk standar (huruf kecil) [9].

Tabel 2. Case Folding Tugas Pokok dan Fungsi

\begin{tabular}{|c|c|}
\hline Teks Asli & Teks Hasil Case Folding \\
\hline $\begin{array}{l}\text { Mengelola buku induk dan kartu santri, } \\
\text { Mengelola surat masuk dan surat keluar, } \\
\text { Menyusun kearsipan pondok, Merealisasikan } \\
\text { Bantuan Operasional Pondok (BOP) dan Dana } \\
\text { Hibah, Menerima dan melayani pendaftaran } \\
\text { santri baru, Mendokumentasikan kegiatan } \\
\text { pondok, Mendata barang Inventaris, } \\
\text { mensosialisasikan peraturan dan kegiatan } \\
\text { pondok kepada wali santri. }\end{array}$ & $\begin{array}{l}\text { mengelola buku induk dan kartu santri, mengelola surat } \\
\text { masuk dan surat keluar, menyusun kearsipan pondok, } \\
\text { merealisasikan bantuan operasional pondok (bop) dan } \\
\text { dana hibah, menerima dan melayani pendaftaran santri } \\
\text { baru, mendokumentasikan kegiatan pondok, mendata } \\
\text { barang inventaris, mensosialisasikan peraturan dan } \\
\text { kegiatan pondok kepada wali santri. }\end{array}$ \\
\hline
\end{tabular}


Tabel 3. Case Folding MPB

\begin{tabular}{|l|l|}
\hline \multicolumn{1}{|c|}{ Teks Asli } & \multicolumn{1}{|c|}{ Teks Hasil Case Folding } \\
\hline $\begin{array}{l}\text { Membuat pengumuman pendaftaran, } \\
\text { menerima berkas pendaftaran, } \\
\text { mengumumkan jadwal tes, melakukan } \\
\text { koreksi, mengumumkan hasil tes. }\end{array}$ & $\begin{array}{l}\text { membuat pengumuman pendaftaran, menerima } \\
\text { berkas pendaftaran, mengumumkan jadwal tes, } \\
\text { melakukan koreksi, mengumumkan hasil tes. }\end{array}$ \\
\hline
\end{tabular}

\section{Filtering}

Filtering merupakan proses untuk membuang katakata yang tidak bermakna dalam dokumen. Daftar kata-kata yang tidak bermakna disimpan dalam sebuah basis pengetahuan bernama stoplist.[8] Stoplist atau yang biasa juga disebut stopword adalah kata-kata yang tidak deskriptif yang dapat dibuang dalam pendekatan bag-of-words (struktur kalimat tidak diperhatikan). Contoh stopword adalah "yang”, "dan”, "di”, “dari” dan lain-lain.[9]

Tabel 4. Filtering Tugas Pokok dan Fungsi

\begin{tabular}{|c|c|}
\hline Teks Hasil Case Folding & Teks Hasil Filtering \\
\hline $\begin{array}{l}\text { mengelola buku induk dan kartu santri, } \\
\text { mengelola surat masuk dan surat keluar, } \\
\text { menyusun kearsipan pondok, merealisasikan } \\
\text { bantuan operasional pondok (bop) dan dana } \\
\text { hibah, menerima dan melayani pendaftaran } \\
\text { santri baru, mendokumentasikan kegiatan } \\
\text { pondok, mendata barang inventaris, } \\
\text { mensosialisasikan peraturan dan kegiatan } \\
\text { pondok kepada wali santri. }\end{array}$ & $\begin{array}{l}\text { mengelola buku induk kartu santri mengelola surat masuk } \\
\text { surat menyusun kearsipan pondok merealisasikan } \\
\text { bantuan operasional pondok bop dana hibah menerima } \\
\text { melayani pendaftaran santri mendokumentasikan } \\
\text { kegiatan pondok mendata barang inventaris } \\
\text { mensosialisasikan peraturan kegiatan pondok wali santri. }\end{array}$ \\
\hline
\end{tabular}

Tabel 5. Filtering Model proses bisnis

\begin{tabular}{|l|l|}
\hline \multicolumn{1}{|c|}{ Teks Hasil Case Folding } & \multicolumn{2}{|c|}{ Teks Hasil Filtering } \\
\hline $\begin{array}{l}\text { membuat pengumuman pendaftaran, menerima } \\
\text { berkas pendaftaran, mengumumkan jadwal tes, } \\
\text { melakukan koreksi, mengumumkan hasil tes. }\end{array}$ & $\begin{array}{l}\text { pengumuman pendaftaran menerima berkas } \\
\text { pendaftaran mengumumkan jadwal tes koreksi } \\
\text { mengumumkan hasil tes. }\end{array}$ \\
& \\
\hline
\end{tabular}

\section{Stemming}

Stemming merupakan proses untuk mencari kata dasar dari setiap kata dalam dokumen dengan membuang imbuhan, baik awalan maupun akhiran. Proses ini menggunakan basis pengetahuan bernama basic-words list sebagai kamus kata dasar. Algoritma stemming yang digunakan adalah dengan memodifikasi algoritma Porter-like Stemmer for Indonesian [8]. Pada tahap ini dilakukan proses pengembalian berbagai bentukan kata ke dalam suatu representasi yang sama. Tahap ini kebanyakan dipakai untuk teks berbahasa Inggris dan lebih sulit diterapkan pada teks berbahasa Indonesia [9]. 
Tabel 6. Stemming Tugas Pokok dan Fungsi

\begin{tabular}{|c|c|}
\hline Teks Hasil Filtering & Teks Hasil Steamming \\
\hline $\begin{array}{l}\text { mengelola buku induk kartu santri mengelola surat } \\
\text { masuk surat menyusun kearsipan pondok } \\
\text { merealisasikan bantuan operasional pondok bop } \\
\text { dana hibah menerima melayani pendaftaran santri } \\
\text { mendokumentasikan kegiatan pondok mendata } \\
\text { barang inventaris mensosialisasikan peraturan } \\
\text { kegiatan pondok wali santri. }\end{array}$ & $\begin{array}{l}\text { Kelola induk kelola surat surat susun arsip realisasi } \\
\text { bantu operasional dana hibah terima daftar } \\
\text { dokumentasi data barang inventaris sosialisasi atur }\end{array}$ \\
\hline
\end{tabular}

Tabel 7. Stemming MPB

\begin{tabular}{|c|c|}
\hline Teks Hasil Filtering & Teks Hasil Stemming \\
\hline 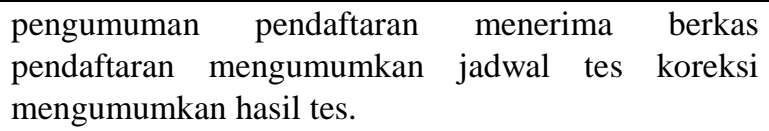 & $\begin{array}{l}\text { umum daftar terima berkas daftar umum jadwal tes } \\
\text { koreksi umum hasil tes }\end{array}$ \\
\hline
\end{tabular}

\section{Tokenizing}

Tokenization merupakan proses untuk memecah teks dokumen menjadi kalimat, kemudian memecahnya menjadi kata-kata. Proses ini juga dilakukan untuk menghilangkan angka, tanda baca dan spasi [8]. Karakter selain huruf dihilangkan dan dianggap delimiter. Delimiter adalah Urutan satu karakter atau lebih yang dipakai untuk membatasi atau memisahkan data yang disajikan dalam kalimat. Salah satu contoh dari delimiter adalah tanda koma, titik koma atau titik dua [9].

Tabel 8. Tokenizing Tupoksi

\begin{tabular}{|l|l|}
\hline \multicolumn{1}{|c|}{ Teks Asli } & \multicolumn{1}{c|}{ Teks Hasil Tokenizing } \\
\hline Kelola & 2 \\
\hline Induk & 1 \\
\hline Arsip & 1 \\
\hline Surat & 2 \\
\hline Atur & 1 \\
\hline Susun & 1 \\
\hline Realisasi & 1 \\
\hline Bantu & 1 \\
\hline Operasional & 1 \\
\hline Data & 1 \\
\hline
\end{tabular}




\begin{tabular}{|l|l|}
\hline Hibah & 1 \\
\hline Terima & 1 \\
\hline Daftar & 1 \\
\hline Dokumentasi & 1 \\
\hline Barang & 1 \\
\hline Inventaris & 1 \\
\hline Sosialisasi & 1 \\
\hline Dana & 1 \\
\hline
\end{tabular}

Tabel 9. Tokenizing Model proses bisnis

\begin{tabular}{|l|l|}
\hline \multicolumn{1}{|c|}{ Teks Asli } & Teks Hasil Tokenizing \\
\hline Umum & 3 \\
\hline Daftar & 2 \\
\hline Terima & 1 \\
\hline Berkas & 1 \\
\hline Jadwal & 1 \\
\hline Tes & 2 \\
\hline koreksi & 1 \\
\hline Hasil & 1 \\
\hline
\end{tabular}

\section{Analisis Data}

Analisis data merupakan suatu langkah yang paling menentukan dari suatu penelitian, karena analisis data berfungsi untuk menyimpulkan hasil penelitian. Analisis data adalah proses mengorganisasikan dan mengurutkan data kedalam pola, kategori, dan satuan uraian dasar sehingga dapat ditemukan tema dan tempat dirumuskan hipotesis kerja seperti yang disarankan oleh data". Langkah-langkah analisis data menurut Miles dan Huberman (1992:15-19), adalah sebagai berikut:

a. Pengumpulan data, yaitu mengumpulkan data di lokasi penelitian dengan melakukan observasi, wawancara, dan dokumentasi dengan menentukan strategi pengumpulan data yang dipandang tepat dan untuk menentukan fokus serta pendalaman data pada proses pengumpulan data berikutnya.

b. Reduksi data, yaitu sebagai proses seleksi, pemfokusan, pengabstrakan, transformasi data kasar yang ada di lapangan langsung, dan diteruskan pada waktu pengumpulan data, dengan demikian reduksi data dimulai sejak peneliti memfokuskan wilayah penelitian.

c. Penyajian data, yaitu rangkaian organisasi informasi yang memungkinkan penelitian dilakukan. Penyajian data diperoleh berbagai jenis, jaringan kerja, keterkaitan kegiatan atau tabel. 
d. Penarikan kesimpulan, yaitu dalam pengumpulan data, peneliti harus mengerti dan tanggap terhadap sesuatu yang diteliti langsung di lapangan dengan menyusun pola pengarahan dan sebab akibat [10]. Analisis data dapat dilakukan melalui tahapan pada gambar 3 berikut ini :

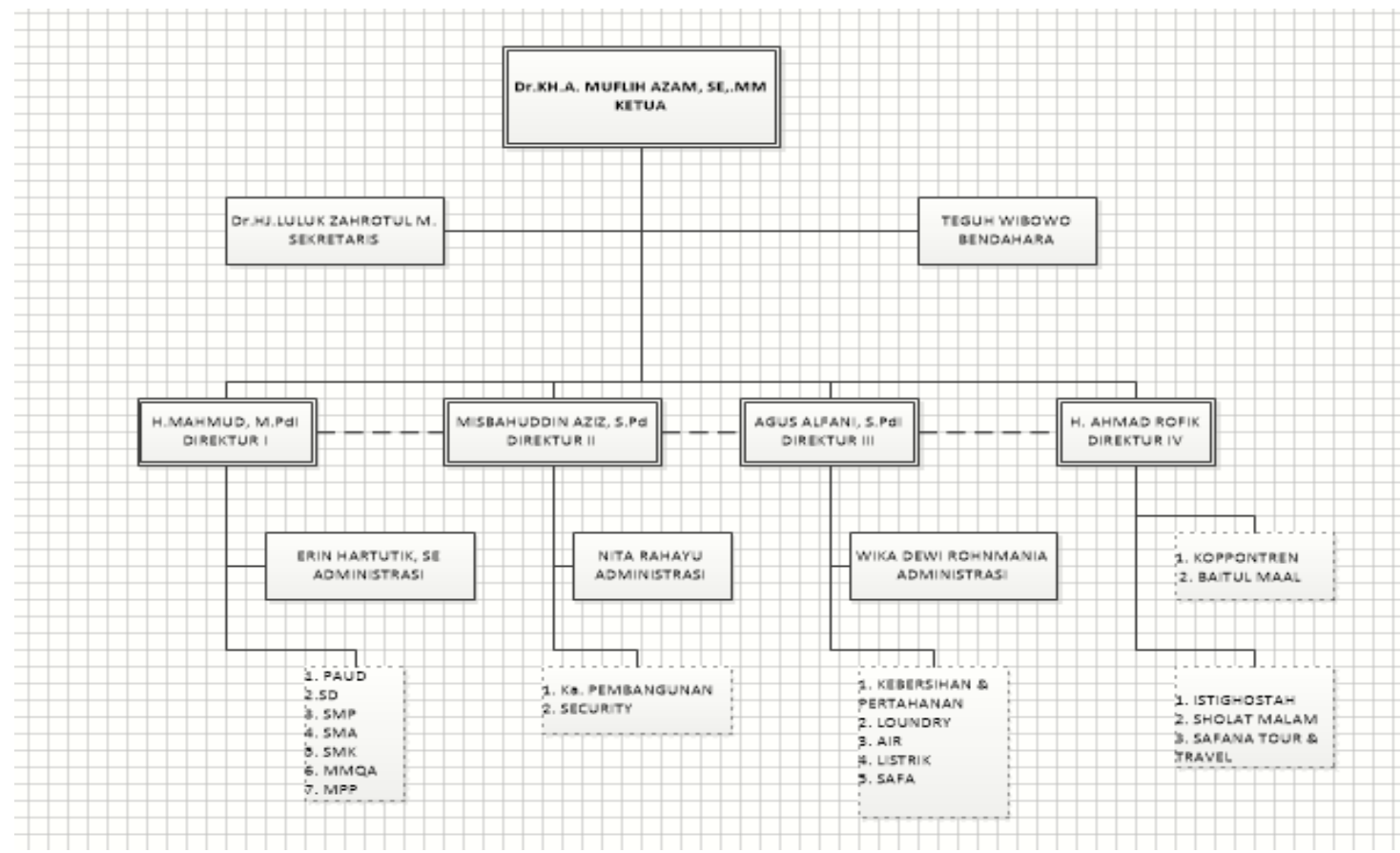

Gambar 3. Struktur Organisasi dengan Microsoft Visio

Pada Gambar 3, merupakan struktur organisasi dari sebuah pondok pesantren dimana terdapat ketua yayasan dari pondok pesantren yang kemudian diikuti oleh staf-stafnya seperti sekretaris, bendahara, seksi, dan para anggota. Sehingga dibentuklah tugas pokok dan fungsi yang memiliki job description masing-masing. Dari job description ini diambil suatu model proses bisnis yaitu kegiatan pendaftaran santri baru.

\section{Pengolahan Data}

Dalam pengolahan data ini akan membuat rancangan software pemetaan struktur organisasi dengan model proses bisnis menggunakan kemiripan makna kata yang sudah diperoleh dari tahap pengumpilan data. Software yang digunakan untuk melakukan preprocess dalam menghitung makna kata yaitu sublime. Kemudian untuk menghitung makana katanya yaitu dengan ws4j menggunakan metode PATH. Sehingga diperoleh pola penelitian, yaitu:

\section{a. Sentence similarity}

Pengolahan data yang dilakukan pada penelitian ini adalah dengan pendekatan semantic similarity yang dihitung menggunakan WS4J (Word Similarity For Java) dengan metode pendekatan PATH. Pada pengukuran ini, sistem akan melakukan perhitungan TF-IDF untuk mendapatkan nilai lexical relevance. Pembobotan TF-IDF digunakan untuk memberikan bobot term terhadap suatu dokumen. Dengan kata lain, TF-IDF juga bisa digunakan untuk mencari keterhubungan satu term yang ada pada teks. TF-IDF direpresentasikan dengan pendekatan vektor, hal ini dikarenakan setiap dokumen di berisi kumpulan kata ( $\mathrm{t} 1, \mathrm{t} 2, \ldots$, tn). Relevansi setiap ti terhadap di berbeda-beda dengan menggunakan perhitungan TF-IDF 
(aris, 2015). Perhitungan TF-IDF menggabungkan perhitungan Term Frequency (tf) dan Inverse Document Frequency (idf) sebagaimana dinotasikan pada Persamaan 1 berikut:

\section{Persamaan $1:$ Wij $=$ tfij $x$ idfj \\ Wij $=$ tfij $x \log (D / i d f j)$}

Dimana Wij adalah bobot term (tj) terhadap dokumen (di). Sedangkan tfij adalah jumlah kemunculan term ( $\mathrm{tj}$ ) dalam dokumen (di). D adalah jumlah semua dokumen yang ada dalam database dan dfj adalah jumlah dokumen yang mengandung term ( $\mathrm{tj}$ ) yang mana minimal ada satu kata yaitu term (tj). Tahap yang akan dilakukan dengan preprocessing text. Pada setiap dokumen dalam koleksi diperlukan mengubah teks menjadi matriks berdasarkan tiap kata yang telah disusun, dengan menghilangkan tanda baca, angka, dan stopword. PATH didefinisikan sebagai similarity dari dua concept berdasarkan kedalaman lcs dan jalur terpendek. Proses perhitungan yang dilakukan oleh PATH adalah mencari jalur terpendek dari setiap concept, kemudian setiap jalur yang terbentuk digabungkan untuk mencari lcsnya. Pencarian LCS (Lowest Common Subsumer) dengan cara mencari sense yang sering dimunculkan dari dua jalur yang dihubungkan. Untuk menghitung sentence similarity diperlukan proses normalisasi dengan menghitung nilai kemiripan kata sebagaimana dapat dilihat pada persamaan 2 berikut :

\section{Persamaan 2 : Sentence similarity $\overline{=(\mathrm{n} \max } * \mathrm{bn}) \overline{+(\mathrm{v} \max } * \mathrm{bv})$}

n max merupakan rata-rata dari jumlah nilai tertinggi tiap kolom matriks kemiripan kata dengan kriteria Noun. v max merupákan rata-rata dari jumlah nilai tertinggi tiap kolom matriks kemiripan kata dengan kriteria Verb. Sedangkan untuk bn dan bv merupakan bobot nilai dari kriteria Noun dan Verb yang telah dihitung menggunakan AHP.

b. Mapping

Untuk perhitungan sentence similarity diberikan perhitungan yaitu jika hasil 2 sentence kemiripannya $<1$ maka proses model bisnisnya akan keluar, namun jika kemiripannya $>1$ maka proses model bisnis tidak akan keluar.

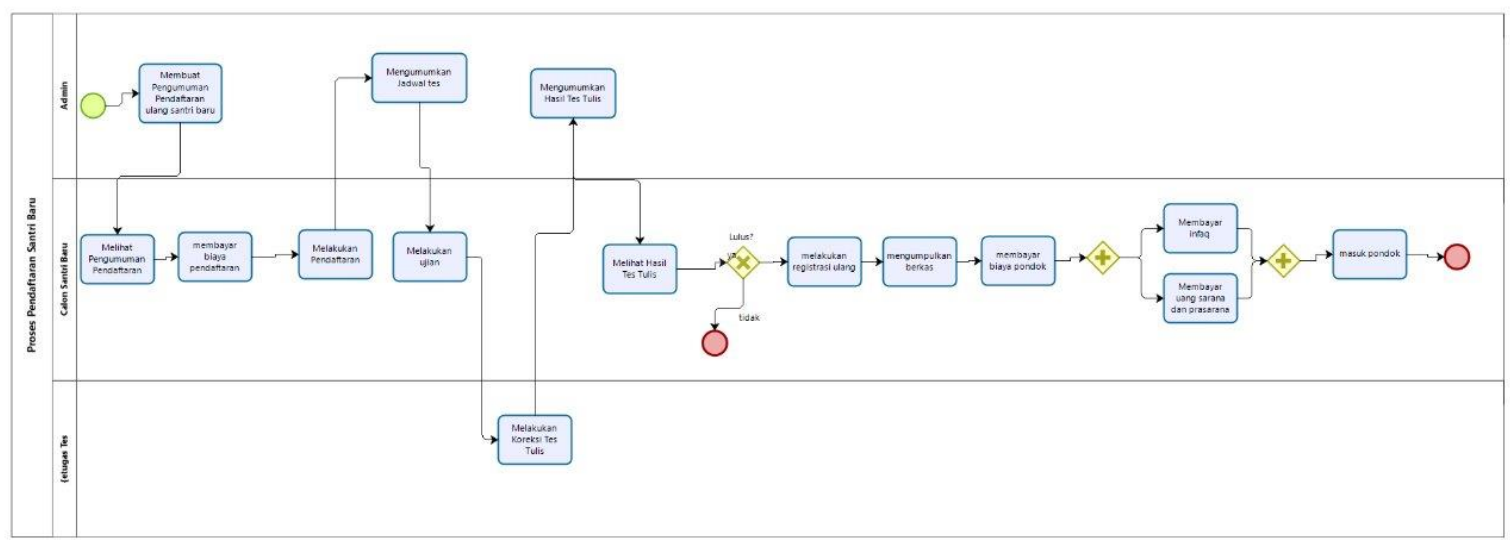

Gambar 4. Mapping Alur Pendaftaran Santri baru dengan Bizagi Modeller

Pada Gambar 4 menjelaskan tentang alur dari model proses bisnis yaitu pendaftaran santri baru yang dimulai dari tahapan membuat pengumuman pendaftaran, menerima berkas pendaftaran, mengumumkan jadwal tes, melakukan koreksi, dan mengumumkan hasil tes santri. 


\section{HASIL DAN PEMBAHASAN}

\section{Sentence similarity (WS4J)}

Tahap awal yang dilakukan dalam proses perhitungan yaitu identifikasi kata dalam proses perhitungan kemiripan kata. Tahap ini dimulai dengan memilah kata yang sesuai dengan jenis atau kriteria katanya. Proses tersebut dilakukan untuk menentukan jenis kata yaitu menggunakan wordNet. Dalam penelitian ini menggunakan WS4J (WordNet Similarity for Java) yang digunakan untuk menghitung nilai kemiripan kata. Dalam perhitungan kemiripan kata menggunakan WS4J terdapat kelas noun, dan verb yang terhitung nilai kemiripannya sehingga tahap identifikasi kalimat ini hanya memilih kata pada kalimat berdasarkan jenis noun, dan verb saja yang kemudian digunakan pada tahap perhitungan word similarity. Berikut adalah kalimat yang digunakan:

- sentence 1: serving the process of registering new students

- sentence 2: notify and make announcements of new student registration

Perhitungan kemiripan antar kata dilakukan dengan pendekatan PATH menggunakan WS4J. Skenario pengujian yang dilakukan yaitu dengan cara melibatkan tiga kriteria tingkat kemiripan kalimat yaitu mirip, sedang, dan tidak mirip. Dibawah ini merupakan contoh perhitungan nilai sentence similarity dari dua contoh kalimat di atas :

\begin{tabular}{|c|c|c|c|c|c|c|c|}
\hline & \begin{tabular}{|l|} 
serving \\
/VBG
\end{tabular} & $\begin{array}{l}\text { the } \\
\text { /DT }\end{array}$ & \begin{tabular}{|l|} 
process \\
/NN
\end{tabular} & $\begin{array}{l}\text { of } \\
\text { /IN }\end{array}$ & $\begin{array}{l}\text { registering } \\
\text { /VBG }\end{array}$ & \begin{tabular}{|l|} 
new \\
$נ$ ננ
\end{tabular} & \begin{tabular}{|l|} 
students \\
/NNS
\end{tabular} \\
\hline notify/VBP & 0.1250 & & - & - & 0.2500 & & \\
\hline \multicolumn{8}{|l|}{ and $/ \mathrm{CC}$} \\
\hline make/VBP & 0.3333 & 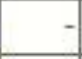 & & & 0.3333 & & \\
\hline announcements/NNS & - & & $\underline{0.1250}$ & & & & $\underline{0.0909}$ \\
\hline \multicolumn{8}{|l|}{ of $/ \mathrm{IN}$} \\
\hline \multicolumn{8}{|l|}{ new $/ 3$} \\
\hline student/NN & -1 & & $\underline{0.1667}$ & & & & 1.0000 \\
\hline registration/NN & - & & $\underline{0.2500}$ & & - & & $\underline{0.0909}$ \\
\hline
\end{tabular}

Gambar 5. Perhitungan dengan PATH

$\Sigma n=0.2500+1.0000=1.2500$

$\mathrm{n}=1.2500 / 2$

$=0.75$

$\Sigma v=0.333+0.3333=0.6666$

$v=0.6666 / 2=0.3333$

$\operatorname{Sim}(0.75,0.25)=(n \times 0.75)+(v x 0.25)$

$=(0.75 \times 0.75)+(0.3333 \times 0.25)$

$=0.6458$

$\operatorname{Sim}(0.25,0.75)=(n \times 0.25)+(v x 0.75)$

$=(0.75 \times 0.25)+(0.3333 \times 0.75)$

$=0.4374$ 


\section{Mapping (TF-IDF)}

Dalam perhitungan, menunjukkan bahwa job description pada sentence 1 dan sentence 2 menunjukkan bahwa nilai setelah dihitung WS4J dan menunjukkan kemiripan data setelah proses normalisasi yaitu bernilai $\mathbf{0 . 6 4 5 8}$ dan $\mathbf{0 . 4 3 7 4}$, dari nilai tersebut menunjukkan perbedaannya kurang dari 3 . Hal ini berarti bahwa 2 sentence tersebut mirip, sehingga akan menampilkan proses model seperti pada gambar 6.

Berikut dibawah ini cara perhitungan bobot dokumen terhadap query dengan menggunakan metode Term Weighting TF-IDF menggunakan rumus yang telah dijelaskan diatas. Berikut adalah kalimat yang digunakan :

- $\quad$ Sentence 1 : serving re-registration of new students

- $\quad$ Sentence 2 : make announcement of re-registration of new students

Query kata $(Q)$ yang digunakan pada penelitian ini yaitu clean, security, dan environment. Sehingga jumlah dokumen dalam koleksi dokumen yaitu $(D)=2$.

$=2 \times(\log (2 / 2)+1)$

Persamaan 3: $W_{\mathrm{ij}}=\mathbf{t}_{\mathrm{fij}} \mathbf{x} \log \left(\mathrm{D} / \mathbf{d}_{\mathrm{fi}}\right)+1$

$=2 \times(0+1)$

$=2$.

Dengan demikian dapat diperoleh nilai bobot (W) untuk setiap kata pada query yang berada di dalam masing-masing dokumen:

Tabel 10. Matriks Term Weighting TF-IDF

\begin{tabular}{|c|c|c|c|c|c|c|c|c|}
\hline & \multicolumn{2}{|c|}{$\mathrm{tf}$} & \multirow[t]{2}{*}{$\mathrm{df}$} & \multirow[t]{2}{*}{$\mathrm{D} / \mathrm{df}$} & \multirow[t]{2}{*}{ IDF } & \multirow[t]{2}{*}{ IDF+1 } & \multicolumn{2}{|c|}{$\mathrm{W}=\mathrm{tf} *(\mathrm{IDF}+1)$} \\
\hline Q & $\mathrm{d} 1$ & $\mathrm{~d} 2$ & & & & & d1 & $\mathrm{d} 2$ \\
\hline Re-registration & 1 & 1 & 2 & 1 & 0 & 1 & 1 & 1 \\
\hline Announcement & 0 & 1 & 1 & 2 & 0.301 & 1.301 & 0 & 1.301 \\
\hline Students & 1 & 1 & 2 & 1 & 0 & 1 & 1 & 1 \\
\hline \multirow{2}{*}{\multicolumn{7}{|c|}{ Nilai bobot setiap dokumen }} & Sum(d1) & Sum(d2) \\
\hline & & & & & & & 2 & 3.301 \\
\hline
\end{tabular}

Pada Tabel 10, menunjukkan bahwa semakin besar nilai perhitungan bobot yang diperoleh maka semakin tinggi juga tingkat kemiripan dokumen terhadap kata (query).

\section{KESIMPULAN}

Berdasarkan hasil penelitian yang telah kami lakukan, dalam pemetaan struktur organisasi dengan model proses bisnis didapatkan tugas pokok dan fungsi dari struktur organisasi tersebut. Pada sebuah organisasi terdapat model proses bisnis yang dilakukan baik berupa event, kegiatan, seminar dan lain sebagainya. Dari struktur organisasi tersebut kemudian dipetakan dengan model proses bisnis yang ada melalui proses dari pengumpulan data, analisis data, dan pengolahan data. Sehingga menghasilkan struktur organisasi yang dipetakan dengan model proses bisnis menggunakan kemiripan makna kata yang menyatakan dari keduanya benar-benar hampir mirip.

\section{REFERENSI}

[1] C. Wijaya, Perilaku individu organisasi. 2017.

[2] M. Daulay, "Peran Organisasi Dakwah dalam Pelaksanaan Bimbingan dan Penyuluhan," HIKMAH J. Ilmu Dakwah dan Komun. Islam, vol. 8, no. 01, pp. 98-106, 2014.

[3] D. Lina, “Analisis Pengaruh Kepemimpinan Dan Budaya Organisasi Terhadap Kinerja Pegawai 
Dengan Sistem Reward Sebagai Variabel Moderating,” J. Ris. Akunt. Dan Bisnis, vol. 14, pp. 77-97, 2014.

[4] R. Yunis, “Arsitektur Bisnis : Pemodelan Proses Bisnis Dengan Object Oriented,” Seminar, vol. 2010, no. semnasIF, pp. 167-173, 2010.

[5] P. F. Opit, "Pemodelan Proses Bisnis Pada Divisi Procurement Di Perusahaan X," J@ Ti Undip J. Tek. Ind., vol. 7, no. 3, pp. 169-174, 2013, doi: 10.12777/jati.7.3.169-174.

[6] T. Slimani, "Description and Evaluation of Semantic Similarity Measures Approaches," Int. J. Comput. Appl., vol. 80, no. 10, pp. 25-33, 2013, doi: 10.5120/13897-1851.

[7] S. Harispe, S. Ranwez, S. Janaqi, and J. Montmain, "Semantic Similarity from Natural Language and Ontology Analysis," Synth. Lect. Hum. Lang. Technol., vol. 8, no. 1, pp. 1-256, 2015, doi: 10.2200/S00639ED1V01Y201504HLT027.

[8] P. M. Prihatini, “151-13-391-1-10-20170222.Pdf,” vol. 6, no. 3, pp. 174-178, 2016.

[9] D. A. Putra and H. Sujaini, "Implementasi Algoritma Rabin-Karp untuk Membantu Pendeteksian Plagiat pada Karya Ilmiah(CONTOH PLAGIAT),” J. Sist. dan Teknol. Inf., vol. 4, no. 1, pp. 66-74, 2015, [Online]. Available: http://jurnal.untan.ac.id/index.php/justin/article/view/12411.

[10] Sugiyono, "Metode Penelitian Kuantitatif, Kualitatif dan R \& D.Bandung:Alfabeta.," Metod. Penelit. Kuantitatif, Kualitatif dan $R$ D.BandungAlfabeta., no. April 2015, pp. 31-46, 2012, doi: 10.1017/CBO9781107415324.004. 